\title{
A dohányzás hatása a fej-nyak régió daganata miatt sebészi terápiában részesült betegek protetikai rehabilitációt követő életminőség-javulására
}

\author{
Nagy Judit dr. ${ }^{1}$ - Novák Péter $d r .^{3}$ - Buzás Kristóf dr. ${ }^{1}$ \\ Nagy Katalin dr. ${ }^{1}$. Antal Márk dr. ${ }^{2}$ \\ Szegedi Tudományegyetem, Fogorvostudományi Kar, 'Szájsebészeti Tanszék, \\ ${ }^{2}$ Konzerváló és Esztétikai Fogászati Tanszék, Szeged \\ ${ }^{3}$ Dental Sopron Fogorvosi Rendelö, Sopron
}

\begin{abstract}
Bevezetés: Ismert, hogy a fej-nyak daganat miatt mútéten átesett betegek rehabilitációja átfogóan és szignifikánsan javítja ezeknek a betegeknek az életminőségét. Célkitüzés: Célunk volt felmérni, hogy a mútétet és a rehabilitációt követő életminőség-javulásban van-e eltérés a dohányzó és nem dohányzó betegeknél. Módszer: Az EORTC H\&N 35 kérdőív segítségével két alkalommal mértük fel 38, fej-nyaki tumor miatt operált (dohányzó és nem dohányzó), majd saját osztályunkon rehabilitált beteg életminőségét, először a mütét után (a gyógyulást követően), majd a rehabilitáció utáni hat hónapos kontroll alkalmával. Eredmények: A dohányzó betegek életminőség-javulása számos aspektusban elmaradt a nem dohányzókétól. Az eredmények alapján a dohányzás nem közvetlenül hat a rehabilitáció sikerességére, hanem önálló hatásai folytán akadályozza meg, hogy a rehabilitáció kifejtse átfogó életminőség-javító hatását. Következtetések: A tanulmány korlátait is figyelembe véve levonható az a következtetés, hogy a fej-nyak régió daganata miatt operált beteg dohányzása jelentősen akadályozza az életminősége javítására tett erőfeszítéseket, ezért a beteget már a diagnózis felállításától kezdve ösztönözni kell, hogy mondjon le káros szokásáról. Orv. Hetil., 2017, $158(5), 172-177$.
\end{abstract}

Kulcsszavak: fej-nyak régió daganatai, életminőség, rehabilitáció, dohányzás, EORTC H\&N 35 kérdőív

\section{The effect of smoking on the quality of life enhancement following prosthetic rehabilitation in head and neck cancer patients who underwent surgical treatment}

Introduction: It is known that the quality of life (QoL) of patients surgically treated for head and neck cancer (HNC) is significantly enhanced by rehabilitation. It is also known that some of these patients will not quit smoking. Aim: To assess if smoking hampers rehabilitation-related QoL enhancement after surgery. Method: Applying the H\&N 35 questionnaire of EORTC, we assessed the QoL of 38 smoking and non-smoking patients who underwent surgical therapy for HNC and subsequent rehabilitation. QoL was assessed after surgery (after the healing period) and 6 months after rehabilitation. Results: While the QoL enhancement of nonsmokers was significant in almost all aspects, that of smoking patients did not reach the level of significance on a number of scales. The results suggest that smoking does not hamper rehabilitation directly, rather, it prevents rehabilitation from exerting its beneficial effects through its own effects. Conclusions: Smoking is a factor that measurably acts against the efforts to enhance the QoL of the surgically treated HNC patient. Therefore, it is essential that emphasis is put on smoking cessation right from the cancer diagnosis also for this reason.

Keywords: cancers of the head and neck region, quality of life, rehabilitation, smoking, EORTC

Nagy, J., Novák, P., Buzás, K., Nagy, K., Antal, M. [The effect of smoking on the quality of life enhancement following prosthetic rehabilitation in head and neck cancer patients who underwent surgical treatment]. Orv. Hetil., 2017, 158(5), 172-177.

(Beérkezett: 2016. október 12.; elfogadva: 2016. november 11.) 


\section{Rövidítések}

BNO = Betegségek Nemzetközi Osztályozása; EORTC H\&N 35 = A European Organization for Research and Treatment of Cancer fej-nyak daganatos betegek életminőségének vizsgálatára kifejlesztett, 35 kérdésből álló mérőeszköze; WHO = World Health Organization

Magyarországon a fej-nyak régió daganatos megbetegedései vezető haláloknak számítanak [1]. Hazánk nemzetközi összehasonlításban is sajnálatosan „elókelő helyet" foglal el ezen megbetegedések incidenciája és prevalenciája szempontjából, amihez minden bizonnyal hozzájárul a dohányzás és alkoholfogyasztás továbbra is jelentôs volta [2]. Annak ellenére, hogy egyre fejlettebb terápiás lehetôségekkel rendelkezünk, a daganat és kezelése még mindig jelentốs szenvedéssel jár, gyakran a túlélők körében is $[3,4]$. A túlélés önmagában tehát csupán részeredménynek tekinthető, amennyiben az nem jár a megfelelő életminőséggel. Ennek megfelelően a daganatos betegek életminősége kiterjedt kutatások tárgyát képezi.

Az életminőséget a WHO a következőképpen definiálja: „...An individual's perception of their own position in life, in the context of the culture and value systems in their life and in relation to their goals, expectations, standards and concerns." Vagyis: Az egyén saját pozíciója az életben, amint azt kultúrája és értékrendszerei keretén belül érzékeli, tekintettel céljaira, elvárásaira, elveire és aggodalmaira. (Az utolső szerző, A. M. fordítása.) [5]. A fej-nyak régió daganatai és ezek kezelése súlyosan ronthatják a beteg életminőségét $[3,6,7]$. Különösen a maxillofacialis régió sebészi terápiájára jellemző, hogy annak folytán az esztétikumot és a funkcionalitást is súlyosan lerontó defektusok maradnak vissza [8-11], amelyek néha olyan mértékben rontják az egyén életminőségét, hogy akár öngyilkossághoz is vezethetnek [12]. Esztétikai szempontból az arcot torzító elváltozások különösen nagy pszichés terhet jelentenek [13], de a rágásra, nyelésre, beszédre való akár csak részleges képtelenség sem kevésbé károsak a beteg életminőségére [14, 15].

Az intra- és extraoralis protetikai rehabilitáció célja éppen az, hogy a keletkezett esztétikai és funkcionális deficitek helyreállításával megakadályozza vagy legalább csökkentse ezt a minőségromlást.

Hazai közlemények is többször beszámoltak arról, hogy a protetikai rehabilitáció alkalmas az életminőség javítására $[16,17]$. Az intraoralis felső állcsonti rehabilitáció leggyakoribb eszköze az obturátor fogprotézis, ami a maxilla daganatainak eltávolítása során keletkező szájpaddefektusok zárására és az elvesztett fogak pótlására szolgál [18]. Noha az eszköz azonnal megszünteti a nyeléssel és a beszéddel kapcsolatos nehézségeket, alkalmazása gyakran jár xerostomiával, valamint higiénés problémák is felmerülhetnek, és ezek önmagukban is befolyásolhatják a beteg életminőségét [19]. A mandibulát a nyelv és a szájfenék daganatai beszúrhetik, ilyen esetek- ben a mandibula részleges eltávolítására kerül sor. A defektus helyreállításának javasolt módja ilyen esetekben szabad vascularizált csontgraft alkalmazása [20], majd konvencionális fogpótlás. Előfordulhat, hogy így sem sikerül megfelelő helyzetet kialakítani a hagyományos fogpótlás számára, ekkor implantátumon elhorgonyzott pótlást alkalmazhatunk.

Az extraoralis rehabilitáció fizikai helyreállításon túlmenó céljai a testkép helyreállítása, a szociális funkció elősegítése és a pszichés károsodás kivédése $[13,21]$. A fej-nyak régió daganatainak és ezek kezelésének kapcsán leggyakrabban elvesztett testrészek az orr, a szemek és a fülek. A pótlások rögzítése történhet adhezív anyagok alkalmazásával, az adott terület anatómiai adottságainak kihasználásával, de erre a célra is jól használhatók az osszeointegrált implantátumok [22].

Korábbi tanulmányunkban két eltérô mérôeszköz segítségével elsőként mutattuk meg, hogy a mútét utáni intra- és extraoralis rehabilitáció szignifikáns javulást okoz a fej-nyak régió daganatai miatt operált betegek életének szinte minden fontos aspektusában [23].

Ismert ugyanakkor, hogy ezen daganatoknak a dohányzás jelentôs kóroki tényezője [24], és az is, hogy a dohányzó betegek igen nagy része betegsége ellenére sem mond le erról a káros szokásról $[25,26]$. Saját tapasztalataink alapján ehhez annyit tehetünk hozzá, hogy betegeinkben sokszor még akkor sem merül fel a leszokás gondolata, ha már mútétre került a sor, aminek következtében egy vagy több testrészüket elvesztették.

Mivel a dohányzás káros hatásai jól ismertek és dokumentáltak, felmerült a kérdés, miként befolyásolhatja a rehabilitáció életminőségre gyakorolt jótékony hatását az, ha a beteg nem hagy fel a dohányzással. Jelen tanulmányunkban, korábbi vizsgálatunk mintegy kiterjesztéseként, erre a kérdésre kerestünk választ.

\section{Módszer}

A vizsgálathoz az 1998-2015 közötti időszakban a Szegedi Tudományegyetem klinikáin a fej-nyak régió daganata miatt (BNO C00-Cl4) mútéten, majd intra- és/ vagy extraoralis rehabilitáción átesett összesen 104 beteg közül 38 beteg adatait használtuk fel $\left(\mathrm{n}_{\text {nó }}=15 ; \mathrm{n}_{\text {férfi }}=23\right.$, átlagéletkor $=66,08$ év). Az, hogy a betegeknek ebbe a vizsgálatba mindössze $37 \%$-át tudtuk bevonni, annak következménye, hogy a beválogatásnál számos szempontot figyelembe kellett vennünk. A bevont betegeket úgy válogattuk, hogy 50\%-uk dohányzó, 50\%-uk pedig nem dohányzó legyen, és az így kialakított két csoport életkor tekintetében is megfeleljen egymásnak. Szempont volt az is, hogy a két csoportba kerülő betegek között az egyes rehabilitációtípusok hasonlóan oszoljanak meg, és mivel irodalmi adatok alapján más krónikus betegség egyidejú megléte ebben a betegcsoportban szignifikánsan befolyásolja az életminőség-vizsgálatot [27], az ilyen betegségekben szenvedőket is ki kellett zárnunk. Nem dohányzó kategóriába azt soroltuk, aki saját bevallása 
szerint élete során soha nem volt dohányos, dohányzónak azt tekintettük, aki saját bevallása szerint a megkérdezés időpontjában is aktív dohányos volt. A dohányzást úgy definiáltuk, mint azt a szokásszerü viselkedést, amelynek során a személy dohány égetéséből származó füstöt inhalációval juttat a szervezetébe, tehát a dohányfogyasztás más formáival nem foglalkoztunk.

Az életminőség vizsgálatára az EORTC H\&N 35 kérdőívének [28] hivatalos magyar változatát alkalmaztuk. A mérőeszköz 18 skálán, összesen 35 kérdéssel méri fel a fej-nyak daganatos beteg életminőségét (1. táblázat). A skálákat funkcionális és általános tüneti skálákra osztjuk, elöbbiek esetében a magasabb pontszám állapotjavulást jelent (például jobban képes beszélni), utóbbiak esetében pedig a pontszám csökkenése jelenti ugyanezt (például kevesebb fájdalomcsillapítóra szorul). Egy-egy skála 0-100-ig terjedő intervallumon jellemzi az általa vizsgált paramétert. Erre az eszközre azért esett a választásunk, mert rövid (a beteg számára jól tolerálható), kifejezetten erre a betegcsoportra fejlesztették ki, irodalma jelentős, és korábban már használtuk, tehát kiértékelését nagy biztonsággal tudtuk elvégezni. A betegek a kérdőívet kétszer töltötték ki. Az első alkalomra a mütéti beavatkozást követően, de már gyógyult állapotban, ugyanakkor még a rehabilitáció előtt került sor (átlagosan két hónappal a beavatkozás után). A személyre szabott pótlások, protézisek elkészítése átlagosan 1,5 hónapot vett igénybe. A kérdőív második kitöltésére a rehabilitációt (a protetikai eszközök be-, illetve felhelyezését) követó

1. táblázat $\mid$ Az EORTC H\&N 35 skálái. A funkcionális skálákat (magasabb pontszám = jobb funkció!) világosszürke háttérrel emeltük ki

\begin{tabular}{|c|c|c|}
\hline Skála & Vizsgált paraméter & $\begin{array}{l}\text { A skálát alkotó } \\
\text { kérdések sorszáma }\end{array}$ \\
\hline HNPA & Fájdalom & $1-4$ \\
\hline HNSW & Nyelés & $5-8$. \\
\hline HNTE & Problémák a fogakkal & 9. \\
\hline HNOM & Szájnyitás & 10 \\
\hline HNDR & Szájszárazság & 11. \\
\hline HNSS & Viszkózus nyál & 12. \\
\hline HNSE & Szaglási, ízlelési eltérések & 13,14 \\
\hline HNCO & Köhögés & 15 \\
\hline HNSP & Beszédproblémák & $16 ., 23 ., 24$. \\
\hline HNFI & Szubjektív betegségérzet & 17. \\
\hline HNSC & Nehezített társas élet & $18 ., 25-28$ \\
\hline HNSO & Nehezített társas étkezés & $19-22$ \\
\hline HNSX & A szexuális élet minősége & $29 ., 30$. \\
\hline HNPK & Fájdalomcsillapító-használat & 31. \\
\hline HNNU & $\begin{array}{l}\text { Táplálékkiegészítők } \\
\text { szükségessége }\end{array}$ & 32. \\
\hline HNFE & Táplálkozáshoz cső szülkséges & 33. \\
\hline HNWL & Testsúlyvesztés & 34. \\
\hline HNWG & Testsúlygyarapodás & 35. \\
\hline
\end{tabular}

hatodik hónapban, egy rutinvizsgálat alkalmával került sor. Az elemzés során az ezen két alkalommal kitöltött kérdőívek egyes skáláinak pontszámait hasonlítottuk össze.

$\mathrm{Az}$ adatok elemzésére az EORTC instrukciói szerint, skálánként, a Statistica for Windows 21.0 (StatSoft, Amerikai Egyesült Államok) segítségével került sor. A normáleloszlási feltétel vizsgálata után a rehabilitáció előtti és a rehabilitáció utáni pontszámokat varianciaanalízis (ANOVA) segítségével hasonlítottuk össze, 5\%-os szignifikanciaszint alkalmazásával.

A vizsgálatban alkalmazott minden eljárás megfelelt a Helsinki Nyilatkozat követelményeinek, a protokollt a Szegedi Tudományegyetem Regionális Humán Orvosbiológiai Kutatási Bizottsága jóváhagyta. A betegek részvétele önkéntes volt, és minden esetben teljes körü szóbeli és írásbeli tájékoztatás előzte meg. A betegek részvételük önkéntességét és informált mivoltát minden esetben beleegyező nyilatkozat aláírásával igazolták.

\section{Eredmények}

Nem dohányzó betegeink esetében a 18-ból 16 skála szignifikáns életminőség-javulást mutatott. A táplálékkiegészítők szedésének szüikségessége és a testsúlygyarapodás tekintetében nem találtunk szignifikáns változást ( $\mathrm{p}=$ $0,12, p=0,15$, az említés sorrendjében). Jellemző, hogy a rehabilitáció után nem csupán a pontszámok változtak, hanem - kevés kivétellel - az átlagok szórása is kisebb lett, ami arra utal, hogy az egyes betegek közötti különbségek az adott skálákon csökkentek, tehát az életminőség nem csupán javult, hanem a vizsgált betegcsoport életminőség szempontjából homogénebbé is vált (2. táblá$z a t)$.

Kiemelendő, hogy a változások több skála esetén (fájdalom, nyelés, beszéd, szubjektív betegségérzet) számszerüen is nagynak bizonyultak, tehát nem csupán alacsony hibaszázalék mellett voltak megállapíthatók. Így például a nyelési funkció átlagpontszáma több mint duplájára emelkedett, és a fájdalomérzet pontszáma jóval kevesebb mint a felére esett vissza a rehabilitáció előtti állapothoz viszonyítva.

Dohányzó betegeink esetében a javulás kevésbé hatott ki az életminőség egészére, ugyanakkor a nem dohányzókkal közös jellemző, hogy amennyiben egy adott skálán a javulás szignifikáns volt, az sok esetben nagy is volt. A dohányzók szubjektív fájdalomérzete például a nem dohányzókéhoz hasonlóan masszív csökkenést mutatott, de a nyelésre való képesség javulása is hasonló mértékű volt. Jellemző ebben a körben még a társas étkezés jelentős javulása, és szubjektív betegségérzet csökkenése is (3. táblázat).

Dohányosok esetében a 18-ból hat olyan skálát találtunk, amelyeken nem állt be szignifikáns változás, noha kifejezett romlást sem észleltünk. Ezek a szájszárazság, a viszkózus nyál, a szaglási/ízlelési eltérések, a köhögés, valamint a szexuális élet minősége és a táplálékkiegészítő- 
A rehabilitáció előtti és utáni állapot közötti eltérés átlagpontszámokkal és szórásokkal az EORTC H\&N 35 egyes skáláin, nem dohányzó betegeknél. A szignifikáns eltérést nem mutató skálákat (lásd 3. táblázat) világosszürke háttérrel emeltük ki. A p-értékek a rehabilitáció előtti és utáni állapot közötti különbség szignifikanciaszintjét mutatják (ANOVA)

\begin{tabular}{|c|c|c|c|c|c|c|}
\hline Skála & $N$ & $\begin{array}{l}\text { Átlag } \\
\text { előtte }\end{array}$ & SD & $\begin{array}{l}\text { Átlag } \\
\text { utána }\end{array}$ & SD & $\mathrm{p}$ \\
\hline HNPA & 19 & 50,00 & 30,17 & 12,28 & 5,05 & $<0,001$ \\
\hline HNSW & 19 & 42,11 & 29,72 & 89,04 & 16,20 & $<0,001$ \\
\hline HNOM & 19 & 43,86 & 33,43 & 73,68 & 32,54 & $<0,05$ \\
\hline HNTE & 19 & 40,35 & 37,81 & 14,04 & 9,08 & $<0,05$ \\
\hline HNDR & 19 & 57,89 & 39,82 & 29,82 & 9,18 & $<0,05$ \\
\hline HNSS & 19 & 52,63 & 35,69 & 17,54 & 8,14 & $<0,05$ \\
\hline HNSE & 19 & 42,98 & 32,07 & 11,40 & 5,67 & $<0,001$ \\
\hline HNCO & 19 & 29,82 & 20,67 & 8,77 & 2,73 & $<0,05$ \\
\hline HNSP & 19 & 53,22 & 27,11 & 91,81 & 26,08 & $<0,001$ \\
\hline HNFI & 19 & 66,67 & 33,33 & 19,30 & 5,08 & $<0,001$ \\
\hline HNSC & 19 & 58,95 & 27,78 & 92,98 & 33,05 & $<0,001$ \\
\hline HNSO & 19 & 42,11 & 32,57 & 81,58 & 24,47 & $<0,001$ \\
\hline HNSX & 19 & 75,44 & 34,41 & 92,98 & 13,96 & $<0,05$ \\
\hline HNPK & 19 & 52,63 & 31,30 & 5,26 & 2,94 & $<0,001$ \\
\hline HNNU & 19 & 31,58 & 27,76 & 29,53 & 11,32 & 0,12 \\
\hline HNFE & 19 & 42,11 & 50,73 & 5,26 & 2,41 & $<0,05$ \\
\hline HNWL & 19 & 68,42 & 47,76 & 10,53 & 7,21 & $<0,001$ \\
\hline HNWG & 19 & 15,79 & 10,46 & 36,84 & 18,56 & 0,15 \\
\hline
\end{tabular}

használat voltak. Utóbbi kapcsán ebben a csoportban megjegyzendő, hogy a rehabilitáció előtt és után is az átlagnál nagyobb szórások adódtak, ami miatt ennek a skálának az eredményeit következtetések levonására nem tartjuk alkalmasnak. A szexuális élet minőségének változása igen közel állt a szignifikanciához $(\mathrm{p}=0,07)$, azonban a meglehetősen csekély hatásnagyság miatt joggal mondhatjuk, hogy valóban nem történt jelentős változás.

$\mathrm{Az}$ eredmények úgy foglalhatók össze, hogy míg a nem dohányzó betegeknél a rehabilitáció majdhogynem egészleges életminőség-javulással járt, dohányzók esetében ez a javulás csak részleges volt, és az életminőség bizonyos jól körülírt aspektusainak kapcsán maradt el.

\section{Megbeszélés}

Eredményeink részben megerősítik, részben árnyalják azt a képet, amelyet korábbi hasonló tanulmányunkban a rehabilitáció életminőségre gyakorolt hatásáról felvázoltunk. Megerősítik, mert a nem dohányzó alcsoport esetében a korábbi vizsgálathoz hasonlóan jelentős mértékű életminőség-javulást figyeltünk meg [23], és árnyalják, mert rámutatnak, hogy amennyiben a beteg nem hagy fel a dohányzással, a javulás több fontos aspektusban is elmarad az egyébként elérhető maximumtól. Ez pedig azt jelenti, hogy a dohányzó beteget káros szokása elvág-
3. táblázat |A rehabilitáció előtti és utáni állapot közötti eltérés átlagpontszámokkal és szórásokkal az EORTC H\&N 35 egyes skáláin, a rehabilitáció során és azt követően is dohányzó betegeknél. A szignifikáns eltérést nem mutató skálákat (lásd 2. táblázat) világosszürke háttérrel emeltük ki. A p-értékek a rehabilitáció előtti és utáni állapot közötti különbség szignifikanciaszintjét mutatják (ANOVA)

\begin{tabular}{|c|c|c|c|c|c|c|}
\hline Skála & $N$ & $\begin{array}{l}\text { Átlag } \\
\text { elötte }\end{array}$ & SD & $\begin{array}{l}\text { Átlag } \\
\text { utána }\end{array}$ & SD & $\mathrm{p}$ \\
\hline HNPA & 19 & 41,23 & 26,71 & 7,46 & 3,42 & $<0,001$ \\
\hline HNSW & 19 & 47,81 & 34,79 & 92,11 & 11,94 & $<0,001$ \\
\hline HNTE & 19 & 26,32 & 30,59 & 7,02 & 5,96 & $<0,05$ \\
\hline HNOM & 19 & 61,40 & 38,91 & 89,47 & 22,37 & $<0,001$ \\
\hline HNDR & 19 & 49,12 & 30,78 & 31,58 & 14,20 & 0,13 \\
\hline HNSS & 19 & 47,37 & 25,55 & 36,84 & 29,18 & 0,36 \\
\hline HNSE & 19 & 31,58 & 27,72 & 14,04 & 9,92 & 0,06 \\
\hline $\mathrm{HNCO}$ & 19 & 24,56 & 11,12 & 19,30 & 8,65 & 0,59 \\
\hline HNSP & 19 & 53,22 & 25,81 & 93,57 & 10,02 & $<0,001$ \\
\hline HNFI & 19 & 73,68 & 37,81 & 10,53 & 5,37 & $<0,001$ \\
\hline HNSC & 19 & 65,96 & 21,99 & 94,39 & 8,68 & $<0,001$ \\
\hline HNSO & 19 & 47,37 & 23,74 & 91,23 & 10,57 & $<0,001$ \\
\hline HNSX & 19 & 71,93 & 32,89 & 88,60 & 20,83 & 0,07 \\
\hline HNPK & 19 & 57,89 & 50,73 & 10,53 & 7,54 & $<0,001$ \\
\hline HNNU & 19 & 26,32 & 35,24 & 9,15 & 31,53 & 0,22 \\
\hline HNFE & 19 & 42,11 & 22,73 & 0,00 & 0,00 & $<0,001$ \\
\hline HNWL & 19 & 84,21 & 37,46 & 0,00 & 0,00 & $<0,001$ \\
\hline HNWG & 19 & 5,26 & 2,94 & 31,58 & 17,76 & $<0,05$ \\
\hline
\end{tabular}

ja annak a lehetőségétől, hogy a csonkoló mútét után általános életminősége a lehető legteljesebb mértékben helyreálljon.

Bizonyos értelemben egyáltalán nem meglepő, hogy az életminőség mely vonatkozásaiban maradt el a szignifikáns javulás dohányzó betegeink körében. Ismert például, hogy a hosszú távú dohányzás szignifikánsan csökkenti a nyálelválasztást, ami által xerostomiához vezet [29]. Természetesen ilyen mellékhatása például a radioterápiának is van, de amíg a nem dohányzó betegek ebben a vonatkozásban jelentős javulásról számoltak be, a dohányzóknál ez a javulás nem mutatkozott. Kétséges, hogy ez mennyiben lehet közvetlenül a rehabilitáció hatása. Jóval valószínúbb, hogy a dohányzás hiánya a rehabilitációtól függetlenül segíti elő a gyógyulási folyamatokat, és az életminőség azon vonatkozásainak javulása, amelyek valóban a protetikai beavatkozás miatt javulnak (például beszéd, társas érintkezés), kihat ennek a tényezőnek a szubjektív megélésére is. Hasonlóképpen magyarázható (és szorosan kapcsolódó) kérdés a nyál viszkozitásának kérdése is. Míg a száraz száj és a viszkózusabb nyál a krónikus dohányosoknak egyébként is problémái, a nem dohányosok körében megfigyelt igen jelentős javulás aligha tudható be közvetlenül a rehabilitációnak. A szaglás és ízlelés tompább mivolta szintén olyan - öszszefüggő - jelenségek, amelyek dohányosoknál jól doku- 
mentáltak [30-33]. A szaglás és ízlelés minősége rehabilitációval befolyásolható [34]. Annak ellenére, hogy ezt föképpen laryngectomia kapcsán igazolták, könnyen belátható, hogyan javíthatja az ízlelést például az, ha a szájüreg folytonossági hiányait kitöltve helyreállítjuk a rágás és nyelés folyamatát vagy ha orr-epithesis alkalmazásával visszaállítjuk a szaglóhám felé irányuló légáramlást. Ebben az esetben tehát nem egyértelmú, hogy az általános életminőség-javulásnak pusztán egy másodlagos hatása marad el a dohányzó betegeknél: lehetséges, hogy a tartós dohányzás kapcsán kialakult érzékszervi változások miatt nem tudnak profitálni a rehabilitációból. Khan és mtsai például a nyelv fungiformis papilláinak jelentős számbeli csökkenését mutatták ki dohányosoknál [32]. Érthető, hogy amennyiben az ízérző felület egy része egyéb okból elpusztul, a daganatos megbetegedés kapcsán alkalmazott rehabilitáció önmagában az ízérzést visszaadni nem lehet képes.

A köhögés mint életminőséget rontó tényező szintén olyan probléma, amit a rehabilitáció enyhíthet, amennyiben a problémát például a mútét folytán megváltozott anatómiai viszonyok váltják ki vagy súlyosbítják, és nem egy állandóan jelen lévő irritatív tényező okozza. A dohányzás kapcsolata a krónikus köhögéssel jól ismert [35]. Noha a „dohányzók köhögésének” kialakulása teljes egészében nem tisztázott kérdés, bizonyos tényezők hozzájárulása szinte biztosra vehető. Kísérletes modellekben például igazolást nyert a dohányfüst előidézte neurogén gyulladás (és a következményes köhögési reflexküszöb-csökkenés) szerepe [36-38], szövettanilag pedig közvetlenül emberben is igazolható a légutak csillóinak morfológiai és funkcionális elégtelensége, ami a mucociliaris clearance elégtelenségét vonja maga után [39]. Látható, hogy dohányzó és nem dohányzó betegeinknek a köhögés a rehabilitáció előtt körülbelül hasonló mértékben jelentett problémát, de amíg a nem dohányzó betegeknél ebben a vonatkozásban látványos javulás állt be, a dohányzó betegeknél a változás minimálisnak volt mondható.

A tápszerek, illetve táplálékkigészítők szükségességének változására nézve a rendkívül nagy szórások miatt, véleményünk szerint, nem lehetséges érvényes következtetéseket levonni. Elképzelhető, hogy ebben a vonatkozásban valóban extrém nagy az egyes betegek eltérése, de ennek vizsgálatához jóval nagyobb mintára lenne szükség.

Hasonlóan nehéz azzal kapcsolatban érvelni, miért marad el a szexuális élet szignifikáns javulása dohányzóknál és miért következik be nem dohányzóknál. Lehetséges, hogy itt ismét arról van szó, hogy ez a változás az általános életminőség-javulás következménye, vagy hogy az átfogó javulás (ami a dohányosoknál nem teljes körü) ennek az egyén általi értékelésére hat ki. A megfelelő részletességú adatok hiányában azonban ezt a kérdést legfeljebb spekuláció szintjén tárgyalhatnánk.

Eredményeinkből, ezek összességében, az tűnik ki, hogy a dohányzás fej-nyak daganat miatti mútéti beavat- kozást és az azt követő rehabilitációt követően lerontja annak az esélyét, hogy a beteg életminősége átfogóan javul. Az eredményekből az is világos, hogy a dohányzás a rehabilitációtól függetlenül tart fenn olyan eltéréseket, amelyek végül akadályát képezik annak, hogy a rehabilitáció a szubjektív módon megélt életminőség egészére fejthessen ki hatást.

Tudjuk, hogy ma Magyarországon a dohányzás még mindig igen elterjedt $[40,41]$, noha úgy tünik, a törvényi szabályozás valóban kedvező változásokat hozhat. Mivel a krónikus dohányzás mellé szokás szerint krónikus alkoholfogyasztás is társul, nem meglepő, hogy hazánkban a fej-nyak régió daganatai igen elterjedtek. Természetesen a primer prevenció alapvető fontosságú, de betegeink kezét a tercier prevenció szakaszában sem engedhetjük el. Az pedig látható, hogy a dohányzás egyébként kiküszöbölhető tényezője még ebben a szakaszban is rombol. Természetesen a beteget káros szokásáról erővel leszoktatni nem lehet, ennek a döntésnek a beteg saját elhatározásából kell megszületnie. Azt viszont jelen tanulmány korlátai között kimondhatjuk, hogy a fejnyak régió daganata miatt operált beteg rehabilitációja, amennyiben a beteg dohányzik, legfeljebb félsiker lehet. Ekkor pedig mi magunk félmunkát végzünk, betegünk pedig nem éri el a gyógyulásnak és életminőség-javulásnak azt a fokát, ami egyébként lehetséges lenne. Ennek tudatában, valamint a dohányzás általános egészségkárosító és a gyógyulást hátráltató hatásaira is figyelemmel, már a diagnózistól kezdődően törekednünk kell arra, hogy a betegben feltámadjon az igény a dohányzás elhagyása iránt.

Anyagi támogatás: A közlemény megírása és az alapját képező kutatómunka anyagi támogatásban nem részesült.

Szerzői munkamegosztás: N. J.: Rehabilitációs munka, kérdőívek felvétele, adatfeldolgozás. N. P.: Daganatterápia, a rehabilitáció előkészítő szakasza, a kézirat elkészítése. B. K.: Rehabilitációs munka, a kérdőívek eredményeinek digitalizálása, értékelés. N. K.: A betegek rehabilitációjának egyéni tervezése, a kézirat elkészítése és szakmai kontrollja. A. M.: A kézirat elkészítése, a vizsgálat megtervezése és felügyelete. A cikk végleges változatát valamennyi szerző elolvasta és jóváhagyta.

Érdekeltségek: A szerzőknek nincsenek érdekeltségeik.

\section{Irodalom}

[1] Ferlay, J., Soerjomataram, I., Dikshit, R., et al.: Cancer incidence and mortality worldwide: sources, methods and major patterns in GLOBOCAN 2012. Int. J. Cancer, 2015, 136(5), E359E386.

[2] Dobrossy, L.: Epidemiology of head and neck cancer: magnitude of the problem. Cancer Metastasis Rev., 2005, 24(1), 9-17.

[3] Kazi, R., Sayed, S., Dwivedi, R. C.: Clinical importance of quality of life measures in head and neck cancer. Indian J. Cancer, $2010,47(3), 237-238$. 
[4] Morton, R. P., Izzard, M. E.: Quality-of-life outcomes in head and neck cancer patients. World J. Surg., 2003, 27(7), 884-889.

[5] Sayed, S. I., Elmiyeh, B., Rhys-Evans, P., et al.: Quality of life and outcomes research in head and neck cancer: a review of the state of the discipline and likely future directions. Cancer Treat. Rev., 2009, 35(5), 397-402.

[6] Jones, E., Lund, V. J., Howard, D. J., et al.: Quality of life of patients treated surgically for head and neck cancer. J. Laryngol. Otol., 1992, 106(3), 238-242.

[7] Rogers, S. N., Hannah, L., Lowe, D., et al.: Quality of life 5-10 years after primary surgery for oral and oro-pharyngeal cancer. J. Craniomaxillofac. Surg., 1999, 27(3), 187-191.

[8] Watson, R. M., Welfare, R. D., Islami, A.: The difficulties of prosthetic management of edentulous cases with hemi-mandibulectomy following cancer treatment. J. Oral Rehabil., 1984, 11(3), 201-214.

[9] Kudo, K., Fujioka, Y.: Review of bone grafting for reconstruction of discontinuity defects of the mandible. J. Oral Surg., 1978, 36(10), 791-793.

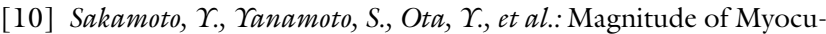
taneous Flaps and Factors Associated With Loss of Volume in Oral Cancer Reconstructive Surgery. J. Oral Maxillofac. Surg., 2016, 74(3), 644-649.

[11] Ren, Z. H., Wu, H. J., Wang, K., et al.: Anterolateral thigh myocutaneous flaps as the preferred flaps for reconstruction of oral and maxillofacial defects. J. Craniomaxillofac. Surg., 2014, 42(8), 1583-1589

[12] Baile, W. F., Gibertini, M., Scott, L.: Depression and tumor stage in cancer of the head and neck. Psychooncology, 1992, $1(1)$ $15-24$.

[13] Dropkin, M. J.: Body image and quality of life after head and neck cancer surgery. Cancer Pract., 1999, 7(6), 309-313.

[14] Huryn, J. M., Piro, J. D.: The maxillary immediate surgical obturator prosthesis. J. Prosthet. Dent., 1989, 61(3), 343-347.

[15] Kornblith, A. B., Zlotolow, I. M., Gooen, J., et al.: Quality of life of maxillectomy patients using an obturator prosthesis. Head Neck, $1996,18(4), 323-334$

[16] Kende, D., Szabó, G., Marada, G., et al.: Impact of prosthetic care on oral health related quality of life. [Protetikai terápiás lehetőségek életminőségre gyakorolt hatása.] Fogorv. Sz., 2008, 101(2), 49-57. [Hungarian]

[17] Szabó, G., Kende, D., Marada, G., et al.: Quality of life and prosthodontics. [Életminőség és fogpótlástan.] Fogorv. Sz., 2006, 99(3), 91-98. [Hungarian]

[18] Parr, G. R., Goldman, B. M., Rahn, A. O.: Maxillofacial prosthetic principles in the surgical planning for facial defects. J. Prosthet. Dent., 1981, 46(3), 323-329.

[19] Depprich, R., Naujoks, C., Lind, D., et al.: Evaluation of the quality of life of patients with maxillofacial defects after prosthodontic therapy with obturator prostheses. Int. J. Oral Maxillofac Surg., 2011, 40(1), 71-79.

[20] Chen, Y. B., Chen, H. C., Hahn, L. H.: Major mandibular reconstruction with vascularized bone grafts: indications and selection of donor tissue. Microsurgery, 1994, 15(4), 227-237.

[21] Nagy, K., Pethö, Z., Borbély, L., et al.: Rehabilitation of patients with head and neck tumors, with special attention to psychotherapy. [Fej-nyak daganatos betegek rehabilitációja, kiemelt figyelemmel a pszichés gondozásra.] Fogorv. Sz., 1997, 90(2), 55-59. [Hungarian]

[22] McKinstry, R. L.: Fundamentals of facial prosthetics. ABI Professional Publications, Clearwater, FL, USA, 1995.

[23] Nagy, J., Braunitzer, G., Antal, M., et al.: Quality of life in head and neck cancer patients after tumor therapy and subsequent rehabilitation: an exploratory study. Qual. Life Res., 2014, 23(1), 135-143.

[24] Hashibe, M., Brennan, P., Chuang, S. C., et al.: Interaction between tobacco and alcohol use and the risk of head and neck cancer: pooled analysis in the International Head and Neck Can- cer Epidemiology Consortium. Cancer Epidemiol. Biomarkers Prev., 2009, 18(2), 541-550.

[25] Cooley, M. E., Sipples, R. L., Murphy, M., et al.: Smoking cessation and lung cancer: oncology nurses can make a difference. Semin. Oncol. Nurs., 2008, 24(1), 16-26.

[26] Parsons, A., Daley, A., Begh, R., et al.: Influence of smoking cessation after diagnosis of early stage lung cancer on prognosis: systematic review of observational studies with meta-analysis. BMJ, 2010, 340, b5569.

[27] Korfage, A., Schoen, P. J., Raghoebar, G. M., et al.: Five-year follow-up of oral functioning and quality of life in patients with oral cancer with implant-retained mandibular overdentures. Head Neck, 2011, 33(6), 831-839.

[28] Bjordal, K., Hammerlid, E., Ablner-Elmqvist, M., et al.: Quality of life in head and neck cancer patients: validation of the European Organization for Research and Treatment of Cancer Quality of Life Questionnaire-H\&N35. J. Clin. Oncol., 1999, 17(3), 1008-1019.

[29] Rad, M., Kakoie, S., Niliye, Brojeni F., et al.: Effect of long-term smoking on whole-mouth salivary flow rate and oral health. J. Dent. Res. Dent. Clin. Dent. Prospects, 2010, 4(4), 110-114.

[30] Konstantinidis, I., Chatziavramidis, A., Printza, A., et al.: Effects of smoking on taste: assessment with contact endoscopy and taste strips. Laryngoscope, 2010, 120(10), 1958-1963.

[31] Vennemann, M. M., Hummel, T., Berger, K.: The association between smoking and smell and taste impairment in the general population. J. Neurol., 2008, 255(8), 1121-1126.

[32] Khan, A. M., Narayanan, V. S., Puttabuddi, J. H., et al.: Comparison of Taste Threshold in Smokers and Non-Smokers Using Electrogustometry and Fungiform Papillae Count: A Case Control Study. J. Clin. Diagn. Res., 2016, 10(5), ZC101-ZC105.

[33] Gudziol, H., Graul, J., Bitter, T., et al.: Ability of smelling is reduced reversibly by acute smoking and permanently by chronic smoking. Laryngorhinootologie, 2013, 92(10), 663-666.

[34] Mumovic, G., Hocevar-Boltezar, I.: Olfaction and gustation abilities after a total laryngectomy. Radiol. Oncol., 2014, 48(3), 301-306.

[35] Pisinger, C., Godtfredsen, N. S., Jorgensen, T.: Smoking reduction and cessation reduce chronic cough in a general population: the Inter99 study. Clin. Respir. J., 2008, 2(1), 41-46.

[36] Bergren, D. R.: Chronic tobacco smoke exposure increases cough to capsaicin in awake guinea pigs. Respir. Physiol., 2001, 126(2), 127-240.

[37] Bergren, D. R.: Chronic tobacco smoke exposure increases airway sensitivity to capsaicin in awake guinea pigs. J. Appl. Physiol., 2001, 90(2), 695-704.

[38] Lewis, C. A., Ambrose, C., Banner, K., et al.: Animal models of cough: literature review and presentation of a novel cigarette smoke-enhanced cough model in the guinea-pig. Pulm. Pharmacol. Ther., 2007, 20(4), 325-333.

[39] Leopold, P. L., O'Mahony, M. J., Lian, X. J., et al.: Smoking is associated with shortened airway cilia. PLoS ONE, 2009, 4(12), e8157.

[40] Cselkó, Z., Kovács, G.: Smoking habits in Hungary: analysis based on surveys of the past decade. [Dohányzási szokások Magyarországon: az utóbbi évtized felméréseinek elemzése.] Orv. Hetil., 2013, 154(37), 1454-1468. [Hungarian]

[41] Tombor, I., Paksi, B., Urbán, R., et al.: Epidemiology of smoking in Hungary - a national representative study. [A dohányzás epidemiológiája a magyar népesség körében országos reprezentatív adatok alapján.] Orv Hetil., 2010, 151(9), 330-337. [Hungarian]

(Antal Márk dr.. Szeged, Tisza Lajos krt. 64., 6720 e-mail: antalmarkdr@gmail.com) 